\title{
Screendance: Aesthetics of Media and Consumer Visual Culture
}

Terry Sprague

$T$

here are more differences than similarities between the state of video art in the early nineteen seventies, as Rosalind Krauss describes it in "Video: The Aesthetics of Narcissism," and the current state of screendance. Reflecting on the works of artists such as Vito Acconci, Krauss convincingly argues that "the medium of video is narcissism," that the physical, electronic, video equipment is "merely an appurtenance," and that the video art world has been "deeply and disastrously affected by its relation to mass-media." While "narcissism" indeed characterizes a selected collection of videos from the nineteensixties and the nineteen-seventies, I propose that mediazation and the aesthetics of consumerism more aptly describe the medium of screendance today. Additionally, at a time when video recording devices are more accessible than ever before (i.e. in the form of palm-sized camcorders such as Flipcams, or devices embedded in cell phones, laptops and still cameras), it functions more as an appendage than as an external apparatus. Finally, over the years, screendance-makers' relationship with "mass-media" has been significantly altered by factors such as streaming video, the Internet and social media. First, I will address these issues and then discuss screendances that exemplify different types of relationships with the media, as well as how these screendances integrate the aesthetics of consumer visual culture.

While "narcissism" characterizes a selected collection of videos from the early seventies, it does not describe the overall nature of contemporary screendance in the early-twenty-first century. Certainly screendance artists, like any other artists, are likely self-absorbed to some extent as individuals but, generally speaking, their work does not prevailingly convey messages that speak of narcissism. In fact, since screendance has evolved in such complex and multi-faceted ways, no one word suffices to generalize a genre that produces works ranging from one-minute, in-camera edited, personal narratives to professional-level productions. However, in order to respond to Krauss's use of the term "narcissism," it can be useful as a metaphor to construct a historical context and to make comparisons.

For the sake of this discussion, let us say that the body of water Narcissus, the video artist, encounters and within which he sees his reflection, is a metaphor for the world of video art making. In the early seventies, access to video equipment was a rarity. Like any other new technology, its inherent features held mystery. Artists were arriving at the water's edge of a frontier that had yet to be explored in-depth. Their works were driven by questions about the nature of the form. They were asking: 'Who am I in relation to this form?' 'What does this say about the 'self'?' To create video feedback on a monitor or to turn the camera upside down served as the content of the work. Explorations of the form were compelling enough to serve as the content. Artists were consumed with 
themselves in relation to the form and were "falling in love" with the form, the process, and what they saw in the water's reflection.

By the early twenty-first century, artists had plunged into the waters of video art making, swam through generations of technological innovations, and Narcissus was no longer characterized by a mostly white, male, Western, Euro-American constituency exhibiting work in relatively elitist gallery spaces. Since the cost of video recording devices has decreased and their availability has increased since the early seventies, video production equipment is getting into the hands of a larger, more varied population. Additionally, due to video-recording devices' increased portability, shooting locations have moved far beyond the artist's studio. Most screendance artists take the nature of the form as a given and concern themselves with other artistic questions.

While the questions the video artists in the early seventies were addressing led Krauss to characterize their aesthetics as one of narcissism, a psychological condition, if contemporary screendance were to be described as a condition, I would argue that it would be more aptly described as a sociological or socio-visual cultural condition, due in part, to its relationship with mass media.

The way in which Krauss describes the relationship between video art makers and the mass media in the seventies differs from the relationship of screendance artists with contemporary mainstream media (network news media) and consumer visual culture (Internet imagery, advertising and mainstream Hollywood cinema). According to Krauss, at that time, the "artworld was deeply and disastrously affected by its relation to massmedia" and "that an artist's work be published, reproduced and disseminated through the media has become ... virtually the only means of verifying its existence as art."2 The implication is that the mass media held some amount of authority over the presentation, distribution, and promotion of artists' works, and that the results were "disastrous." Conversely, various factors are contributing to a shift in the relationship contemporary screendance artists have with mass media. With the advent of user-friendly, non-linear, video-editing software and other technological advances, many screendance artists are mastering production techniques, such as professional-level image making, and therefore decreasing the difference between commercial, professional imagery (seen in mass media) and what screendance artists are capable of creating. Additionally, contemporary social media such as Facebook and YouTube provide significant opportunities for artists to "perform," "publish," and promote their work independently of more traditional mass media. By utilizing video technologies, screendance "places itself in the discourse of current media practice and therefore in the discourse of popular culture." ${ }^{3}$

Consequently, different artists' screendances are engaging with current media practice and the discourse of popular consumer culture in different ways, three of which I name here:

1) Some screendances feature imagery that imitates and code-switches with mainstream consumer culture media, which ultimately serves to perpetuate mainstream consumer-culture ideology. Screendances such as Ben Dolphin's Arising (2008) and Pontus Lidberg's The Rain (2007) feature highly-produced, sometimes clichéd, fetishized images of dancers' bodies in costumes such as wet, clinging, shirts or in partial nudity, which resemble images seen in mainstream media and advertising. The exquisitely lit, 
fetishized-landscape images seen in Isabel Rocamora's Horizon of Exile (2007), are not unlike images featured in travel advertising or those seen in high-fashion ads shot in exotic, remote locations. These screendances are creating imagery, which can be interchanged with images seen in media and advertising, that tends to re-enforce more than it subverts mainstream consumer-culture ideology.

2) Conversely, a number of contemporary screendances fall into the category, which Krauss describes near the end of her article: video-art works that "run counter to what I had been saying so far," which include "tapes that exploit the medium in order to criticize it from within."4 Lloyd Newson's Cost of Living (2003) employ the medium of video and the "tools" of the media, in order to critique the media. In Cost of Living, Newson keys into the fact that ideology is perpetuated, in part, when viewers identify with people and objects in mainstream-media representations. He creates an unsettling scene, which subversively disturbs such identification and addresses ways in which network-news media invite identification - not for the purposes of selling a product, as with advertisements - but for the purposes of engaging us in voyeuristic viewing and inviting us to witness sensational images of stories featured in news reports. The scene takes place on a grassy field where an aggressive cameraman is shooting David, the protagonist who has no legs. Initially, Newson aligns the viewer's perspective with that of the cameraman's. Then, unlike network-news media conventions, Newson's camera also hones in on the man behind the camera in a way that interrupts the process of viewer identification with him or with David, the object of the gaze.

Additionally, the cameraman's relentless, invasive curiosity about David's body raises questions about the impact network-news media has on the way we see others and ourselves in terms of desirability and difference. Newson brings our attention to the power of news media's gaze-its entitlement to look and its discomfort with the notion of difference-by shooting close-up and by representing the camera as assaulting and almost weapon-like. In the end, Newson troubles our habitual inclination to identify with either the gazer (the cameraman) or the object of the gaze (David) and brings our awareness to the fact that the media has "trained" us to watch in these ways.

Similarly, in Desert Storm, Ndiritu employs news media and advertising strategies in order to criticize their role in the perpetuation of ideological operations and to bring our attention to ways in which we are encouraged to watch with voyeuristic eyes. Like many of Vito Acconci's videos, Desert Storm is shot with a single camera looking down on Ndiritu's veiled, nude body, as she writhes back and forth upon the floor, which is a map of the world. White text scrolls slowly from right to left on a black strip at the bottom of the screen, listing countries such as Sudan, East Timor, Iraq, Afghanistan, Rwanda, Bosnia, Kashmir, Tibet, Eritrea, Kosovo, Chiapas, Algeria, Congo, Sri Lanka and others countries within which rape has been used as a weapon of war. The scrolling text along the lower edge of the frame resembles the way network news programs display the up-to-theminute news reports, emergencies, and catastrophic events. Networks are known to broadcast in this fashion even during non-news programs. Desert Storm's final message also features white text, which appears on a black screen and reads: "Today's news is tomorrow's war." Between the screendance's title, Desert Storm, the news media-styled scrolling text, and the final words, Ndiritu is most certainly asking us to consider news 
media operations and the role they played in Desert Storm, the operational name for the military response in the Persian Gulf War (1990-1991).

Ndiritu also employs strategies used by media and advertising to hook the viewer such as performing the veiled, nude, female body as an invitation to look. Then, at the end of the screendance, she interrupts our gaze when she abruptly comes from behind the veil and gazes back with intense, almost accusatory eyes. As in Newson's piece, we are made uncomfortably aware of our own watching. After watching her as an object, we are made the object of her gaze with her sudden stare. Ultimately, Nidiritu and Newson are appropriating elements of advertising and news-media strategies, as well as inventing their own, in an effort to be transformative.

3) Some screendance artists are inventing new forms and new ways of constructing screendances. For example, Natalie Bookchin's Mass Ornament (2009) features individual dancers who created media representations of themselves in ways that mimic consumer-culture aesthetics and advertising strategies. Mass Ornament is comprised of "found" YouTube clips of people (mostly women) dancing alone in their rooms. Bookchin edited them according to particular movements, gestures, and particular themes, thereby re-presenting these dancers and constructing a second level of mediation. While the end result evokes the chorus-line style and unison choreography seen in works by choreographers such as Busby Berkeley, The Tiller Girls and Leni Riefenstahl, Bookchin's re-mediation serves to emphasize their humanity as much or more as their bodies as sensuous objects.

The original "found" YouTube clips in Mass Ornament demonstrate both artistmedia relations, which counter Krauss's description of artists' relation with the media in the seventies, and a kind of self-promotion that reflects aspects of consumer-culture aesthetics. While Krauss's description of the artist-media relations implies disaster of some kind, the dancers in the Mass Ornament YouTube clips are demonstrating an authority over their own self-representation. They appear in private, domestic spaces, which by virtue of their display online, are transformed into public stages. Their movements read as expressions of their identities, showing off and, in some cases, celebrating. If anything, they are appropriating media and advertising strategies for their own selfpromotion purposes. They are "advertising" themselves in ways that resemble the way consumer culture advertises products - with contemporary, sensuous, movement, music, and fashion. Unlike the way Krauss describes the authority held by the media in the seventies, the dancers in Mass Ornament are not dependent on mainstream-media producers to get them Internet "air time."

Rather than characterizing contemporary screendance as embodied by Narcissus, enamored with gazing at his own reflection in the water, some contemporary screendance artists are splashing in the water to disturb the reflection, making a fountain with the water, or are gazing back at the viewer on the shore with the intention of causing transformation. They are appropriating media and consumer-culture aesthetics to imitate them, critique them, and/or re-mediate and reconstruct them in inventive ways. 


\section{References}

Bookchin, Natalie. "Mass Ornament."Vimeo video, 7:12, posted by “natalieb," July 1 2009. http://vimeo. com/5403546.

Dolphin, Ben. "Arising." Hulu video, 4:13, January 1, 2008. http://www.hulu.com/watch/133621/ dance-on-camera-arising\#x-4,vclip,1,0.

Krauss, Rosalind. "Video: The Esthetics of Narcissism." October 1 (1976): 50-64.

Lidberg, Pontus. “The Rain.”Vimeo video, 5:36, posted by “Dancefilm," March 28, 2010. http://vimeo. com/10508318.

Ndiritu, Grace. "Desert Storm." Axis video, 5:08, 2004. http://www.axisweb.org/Artwork.aspx?WORKID=54195\&VIS UALID=81594.

Newson, Lloyd. "The Cost of Living." disTHIS! Film Series video, 1:53, 2004. http://disthis.org/CostOfLiving.htm.

Rocamora, Isabel. "Horizon of Exile." Isabel Rocamora video, 2:27, 2007. http://www.isabelrocamora.org/home/ FilmTv/Horizon-of exile/HorizonTrailer/TrailerLarge.html.

Rosenberg, Douglas. "Video Space: A Site for Choreography." Leonardo 33, no.4 (2000): 275-80.

\section{Notes}

1. Rosalind Krauss, "Video: The Aesthetics of Narcissism," 50, 57, 59.

2. Krauss, 59.

3. Rosenberg, "Video Space, " 10.

4. Krauss, 59. 